\title{
SURVIVAL OF APPLE MAGGOT LARVAE, RHAGOLETIS POMONELLA (DIPTERA: TEPHRITIDAE), IN PICKED AND UNPICKED APPLES ${ }^{1}$
}

\author{
W. H. REISSIG \\ New York State Agricultural Experiment Station, Geneva, New York 14456
}

\begin{abstract}
Can Ent. 111: 181-187 (1979)

Apple maggot eggs, Rhagoletis pomonella (Walsh), hatched equally well in apples on the tree and in picked fruit. Many larvae completed development in all different maturities of picked fruit and development and survival were similar in different cultivars. In contrast, larval mortality was high in apples remaining on the tree, particularly in fruit infested in late June and July. More larvae survived in the unpicked fruit of the earlier ripening, softer cultivars, Wealthy and McIntosh, than in the later ripening Rhode Island Greening and Rome apples.
\end{abstract}

\section{Introduction}

Development and survival of apple maggot larvae, Rhagoletis pomonella (Walsh), varies among apple cultivars. Larvae grow more slowly and mortality is greater in later than in early maturing apples (Brittain and Good 1917; Caesar and Ross 1919; Dean and Chapman 1973; Neilson 1976; Cameron and Morrison 1977). These studies usually observed larval growth and mortality only in mature apples which had fallen or been picked in the fall. Since apple maggot females oviposit in immature apples from late June to September in New York State, the ability of eggs to hatch and larvae to develop in different maturities of apples remaining on the tree for various time periods is crucial to the survival of the insect.

In this study, egg hatch and survival of larvae was compared in picked and unpicked apples of several cultivars infested at different times through the season.

\section{Materials and Methods}

1976 tests. On 15 June, several hundred Wealthy, McIntosh, Rhode Island Greening, and Rome apples in an orchard that had received no insecticide were covered with brown paper bags to protect them from insect pests. Each week from 27 June to 26 August, 15 apples of each cultivar were infested while they remained on the tree by confining sexually mature ( $5 \delta$ and $5 \%$ ) laboratory reared apple maggot flies in wire screen sleeve cages over each apple. After ca. 7 days the cages and any surviving flies were removed, the oviposition stings were counted on each apple, and the fruit was again covered with a paper bag. Ten days later, oviposition stings on five apples of each cultivar were dissected to determine if they contained eggs and if the eggs hatched. Four weeks after the test, the remaining infested apples were picked, examined for larval exit holes, and incubated individually in plastic cups containing ca. $2.5 \mathrm{~cm}$ of sand in a biotron $\left(16: 8 \mathrm{LD}\right.$ at $\left.27^{\circ} \mathrm{C}\right)$ for another 4 weeks. Then pupae in the sand were counted and fruit was examined internally to assess damage and any remaining, living larvae. Larvae that developed in each apple were estimated as the sum of the exit holes observed when the fruit was picked and the number of pupae and living mature larvae obtained at the end of each test.

Also, after each weekly field test, uninfested apples of each cultivar were picked and 1 apple/cultivar was placed in each of 15 wire screen cages $(0.9 \times 0.9 \times 0.9 \mathrm{~m})$ containing 25 pairs of reproductively mature laboratory-reared apple maggot flies that were fed sugar, water, and a diet containing casein hydrolysate, salts, and vitamins (Neilson and McAllan 1965). Three to five days later the flies were removed from the cages, oviposition stings were counted, and the fruit was incubated in a biotron (16:8 $\mathrm{LD}, 27^{\circ} \mathrm{C}$ ) for 10 days. Then 10 randomly selected oviposition stings on each of five

'Approved by the Director of the New York State Agricultural Experiment Station as Journal Paper No. 3157. 
apples were dissected to determine if they had eggs, and if the eggs had hatched. The 10 remaining apples were incubated individually in paper cups as previously described for 4 weeks. The number of larvae developing in each apple was estimated as the sum of pupae and mature living larvae found during a final internal examination of each apple.

1977 tests. Fifteen to 20 McIntosh, Rhode Island Greening, and Rome apples were infested on the tree, as previously described, each week from 27 June to 6 September in an unsprayed apple orchard at the New York State Agric. Expt. Station in Geneva. The oviposition stings were counted after each test and half the infested apples of each cultivar were left on the tree and covered with paper bags. On 7 September the apples infested during 27 June-2 July were harvested, examined for larval exit holes, and incubated individually in plastic dishes under natural temperatures and photoperiod in a nearby screened insectary. Each apple was placed on a hardware cloth rack above 2 $\mathrm{cm}$ of water in each dish. The dishes were checked frequently to determine the number of mature larvae that emerged from each apple and drowned in the water. Each week thereafter the successively infested apples were brought into the insectary, until 2 November when all the remaining fruit was collected. On 18 November all appples were cut and examined for living mature larvae and internal damage.

The other half of the fruit infested each week was immediately picked and incubated in the insectary. The dishes were checked every other day and larvae were removed to estimate the rate of development as well as the number surviving in each picked apple. When emergence had ceased, each apple was dissected to detect any remaining mature larvae.

\section{Results}

Differences in the percentage of oviposition stings containing eggs and egg hatch were slight among fruit of different cultivars, and only the combined data are presented in Table I. A high percentage of eggs hatched in both apples remaining on the tree in the field, and picked apples infested in the laboratory throughout the season (Table I). Apples on the tree that were infested early in the season contained more empty oviposition punctures than those infested in late summer.

Large numbers of larvae survived in picked fruit infested and incubated in the laboratory (Table IIA) and in picked apples incubated in the insectary (Table IIB). Similar numbers of larvae survived in different cultivars and in apples infested at different times in the season. Usually the number of oviposition stings was greater than

Table I. Apple maggot, Rhagoletis pomonella, oviposition success and egg hatch in picked and unpicked apples

\begin{tabular}{|c|c|c|c|c|c|}
\hline \multirow[b]{2}{*}{ Test interval } & \multicolumn{2}{|c|}{ Picked apples } & \multicolumn{3}{|c|}{ Apples on tree } \\
\hline & $\begin{array}{c}\text { Stings with } \\
\text { eggs } \\
(\%)\end{array}$ & $\begin{array}{c}\text { Egg } \\
\text { hatch } \\
(\%)\end{array}$ & $\begin{array}{l}\text { No. stings } \\
\text { dissc. }\end{array}$ & $\begin{array}{l}\text { Stings with } \\
\text { eggs } \\
(\%)\end{array}$ & $\begin{array}{c}\text { Egg } \\
\text { hatch } \\
(\%)\end{array}$ \\
\hline $6 / 30-7 / 02$ & 84 & 78 & 205 & 55 & 88 \\
\hline $7 / 03-7 / 09$ & 64 & 81 & 82 & 50 & 93 \\
\hline $7 / 10-7 / 16$ & 54 & 87 & - & - & - \\
\hline $7 / 17-7 / 22$ & 51 & 86 & - & - & - \\
\hline $7 / 23-7 / 27$ & 68 & 97 & - & - & - \\
\hline $7 / 28-8 / 04$ & 82 & 80 & 178 & 73 & 82 \\
\hline $8 / 05-8 / 11$ & 76 & 99 & - & - & - \\
\hline $8 / 12-8 / 18$ & 89 & 82 & - & - & - \\
\hline $8 / 19-8 / 25$ & 95 & 84 & 145 & 90 & 88 \\
\hline
\end{tabular}




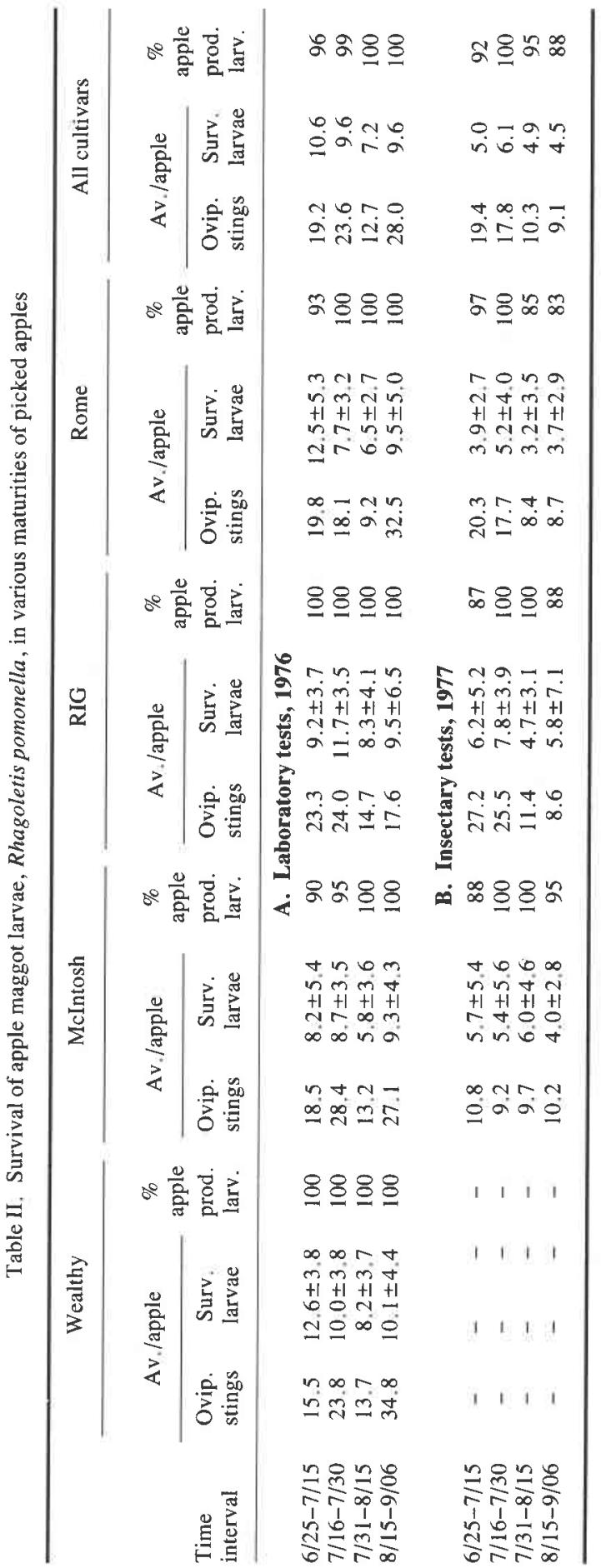


Table III. Rate of development of Rhagoletis pomonella larvae in picked apples

\begin{tabular}{|c|c|c|c|c|c|c|c|c|c|c|c|c|c|}
\hline \multirow{3}{*}{$\begin{array}{l}\text { Test } \\
\text { interval }\end{array}$} & \multicolumn{12}{|c|}{ Days from oviposition to emergence of mature larvae } & \multirow{3}{*}{$\begin{array}{c}\text { Av. } \\
\text { temp. } \\
\left({ }^{\circ} \mathrm{C}\right)\end{array}$} \\
\hline & \multicolumn{3}{|c|}{ Mclntosh } & \multicolumn{3}{|c|}{ RIG } & \multicolumn{3}{|c|}{ Rome } & \multicolumn{3}{|c|}{ All cultivars } & \\
\hline & $1 \mathrm{st}$ & $50 \%$ & Last & $1 \mathrm{st}$ & $50 \%$ & Last & Ist & $50 \%$ & Last & Ist & $50 \%$ & Last & \\
\hline $6 / 25-7 / 15$ & 22 & 25 & 34 & 23 & 28 & 35 & 21 & 25 & 35 & 22 & 26 & 34 & 21.5 \\
\hline $7 / 16-7 / 30$ & 21 & 24 & 35 & 22 & 29 & 39 & 21 & 25 & 35 & 21 & 26 & 36 & 20.3 \\
\hline $7 / 31-8 / 15$ & 27 & 32 & 44 & 26 & 34 & 45 & 28 & 33 & 47 & 27 & 33 & 45 & 19.0 \\
\hline $8 / 16-9 / 06$ & 32 & 42 & 52 & 38 & 49 & 58 & 36 & 45 & 56 & 35 & 45 & 55 & 16.4 \\
\hline
\end{tabular}

${ }^{\mathrm{a}} \mathrm{Av}$. temp. $=\frac{\Sigma(\text { Daily max air temp. }+ \text { min. air temp. }) / 2}{\text { No. of days from date of infestation until the last larvae emerged }}$

the number of larvae the fruit could support; since the excess larvae died, no relationship was observed between the number of oviposition stings and larval survival.

Larvae developed at similar rates in picked apples infested at different times in late June to July and incubated under natural conditions in an insectary, but larvae developed more slowly and remained in the fruit longer as apples were infested later in the season (Table III). Larvae emerged at about the same time from fruit of different cultivars, infested during any given interval of the test. As the season progressed, the temperatures in which larvae developed gradually declined.

Larval mortality was higher in apples remaining on the tree than in picked fruit. Larvae completed their development in only $13 \%$ of the unpicked apples infested from 25 June to 25 July (Table IV), but larvae developed in an increasingly larger percentage as the season progressed. During June and July larvae developed much more successfully in early maturing apples (Wealthy and McIntosh) than apples in the later-maturing (Rhode Island Greening and Rome) apples. Later in the season, differences were not so pronounced although Wealthy apples were still more favorable for survival after mid-August.

When infested apples that had remained on the tree were examined in the fall, the flesh of those in which larvae had completed their development was soft and many were completely rotten inside (Fig. 1B). Apples infested early in the season from which no larvae emerged, remained firm but contained numerous small brown tunnels $<1 \mathrm{~mm}$ in diameter made by small larvae that died early (Fig. 1A). Most of these tunnels were shallow (1-2 cm beneath the skin) although a few penetrated deeper. The flesh of similar apples infested later in the season was also firm during the final examination but larval tunnels were slightly larger $(>1 \mathrm{~mm}$ diam.) and deeper. These small tunnels demonstrated that although eggs hatched well in apples remaining on the tree many larvae died in early instars.

\section{Discussion}

Although apple maggot eggs hatched equally well in apples remaining on the tree and in picked fruit, the survival and development of larvae was different. Most larvae died early in apples that were infested in late June to mid-July and remained on the tree, but survival progressively increased as fruit was infested later in the season. Early in the season, more larvae developed in the unpicked, early maturing, softer Wealthy and McIntosh apples than in the firmer, later ripening Rhode Island Greenings and Romes, although the differences were smaller in August and September. Substantial numbers of larvae survived in picked apples of all cultivars, regardless of when they were infested. The emergence pattern of larvae from picked apples incubated in the insectary under natural conditions was similar in all cultivars harvested on any given date, but the larvae 
Table IV. Survival of apple maggot larvae, Rhagoletis pomonella, in various maturities of picked apples

\begin{tabular}{|c|c|c|c|c|c|c|c|c|c|c|c|c|c|c|c|}
\hline \multirow[b]{3}{*}{$\begin{array}{l}\text { Time } \\
\text { interval }\end{array}$} & \multicolumn{3}{|c|}{ Wealthy } & \multicolumn{3}{|c|}{ McIntosh } & \multicolumn{3}{|c|}{ RIG } & \multicolumn{3}{|c|}{ Rome } & \multicolumn{3}{|c|}{ All cultivars } \\
\hline & \multicolumn{2}{|c|}{ Av./apple } & \multirow{2}{*}{$\begin{array}{c}\% \\
\text { apple } \\
\text { prod. } \\
\text { larv. }\end{array}$} & \multicolumn{2}{|c|}{ Av./apple } & \multirow{2}{*}{$\begin{array}{c}\% \\
\text { apple } \\
\text { prod. } \\
\text { larv. }\end{array}$} & \multicolumn{2}{|c|}{ Av./apple } & \multirow{2}{*}{$\begin{array}{l}\% \\
\text { apple } \\
\text { prod. } \\
\text { larv. }\end{array}$} & \multicolumn{2}{|c|}{ Av./apple } & \multirow{2}{*}{$\begin{array}{l}\% \\
\text { apple } \\
\text { prod. } \\
\text { larv. }\end{array}$} & \multicolumn{2}{|c|}{ Av./apple } & \multirow{2}{*}{$\begin{array}{c}\% \\
\text { apple } \\
\text { prod. } \\
\text { larv. }\end{array}$} \\
\hline & $\begin{array}{l}\text { Ovip. } \\
\text { stings }\end{array}$ & $\begin{array}{l}\text { Surv. } \\
\text { larvae }\end{array}$ & & $\begin{array}{l}\text { Ovip. } \\
\text { stings }\end{array}$ & $\begin{array}{l}\text { Surv. } \\
\text { larvae }\end{array}$ & & $\begin{array}{l}\text { Ovip. } \\
\text { stings }\end{array}$ & $\begin{array}{l}\text { Surv. } \\
\text { larvae }\end{array}$ & & $\begin{array}{l}\text { Ovip. } \\
\text { stings }\end{array}$ & $\begin{array}{l}\text { Surv. } \\
\text { larvae }\end{array}$ & & $\begin{array}{l}\text { Ovip. } \\
\text { stings }\end{array}$ & $\begin{array}{l}\text { Surv. } \\
\text { larvae }\end{array}$ & \\
\hline $6 / 25-7 / 15$ & 15.0 & $0.6 \pm 1.1$ & 32 & 12.8 & $0.3 \pm 1,1$ & 12 & 27.8 & $0.3 \pm 1.0$ & 8 & 20.6 & $0.2 \pm 1.6$ & 4 & 19.4 & 0.4 & 13 \\
\hline $7 / 16-7 / 30$ & - & - \pm- & - & 10.8 & $0.9 \pm 1.1$ & 41 & 19.4 & $0.2 \pm 0.9$ & 7 & 11.8 & $0.2 \pm 0.8$ & 7 & 13.8 & 0.4 & 16 \\
\hline $7 / 30-8 / 15$ & - & - \pm- & - & 5.7 & $2.2 \pm 4.0$ & 33 & 17.9 & $0.9 \pm 1.4$ & 41 & 7.1 & $2.7 \pm 3.6$ & 55 & 10.6 & 1.9 & 45 \\
\hline $8 / 16-9 / 06$ & 9.1 & $5.7 \pm 4.9$ & 89 & 7.6 & $1.3 \pm 1.7$ & 59 & 10.4 & $1.6 \pm 2.9$ & 35 & 13.9 & $1.8 \pm 2.5$ & 48 & 10.6 & 2.0 & 53 \\
\hline
\end{tabular}




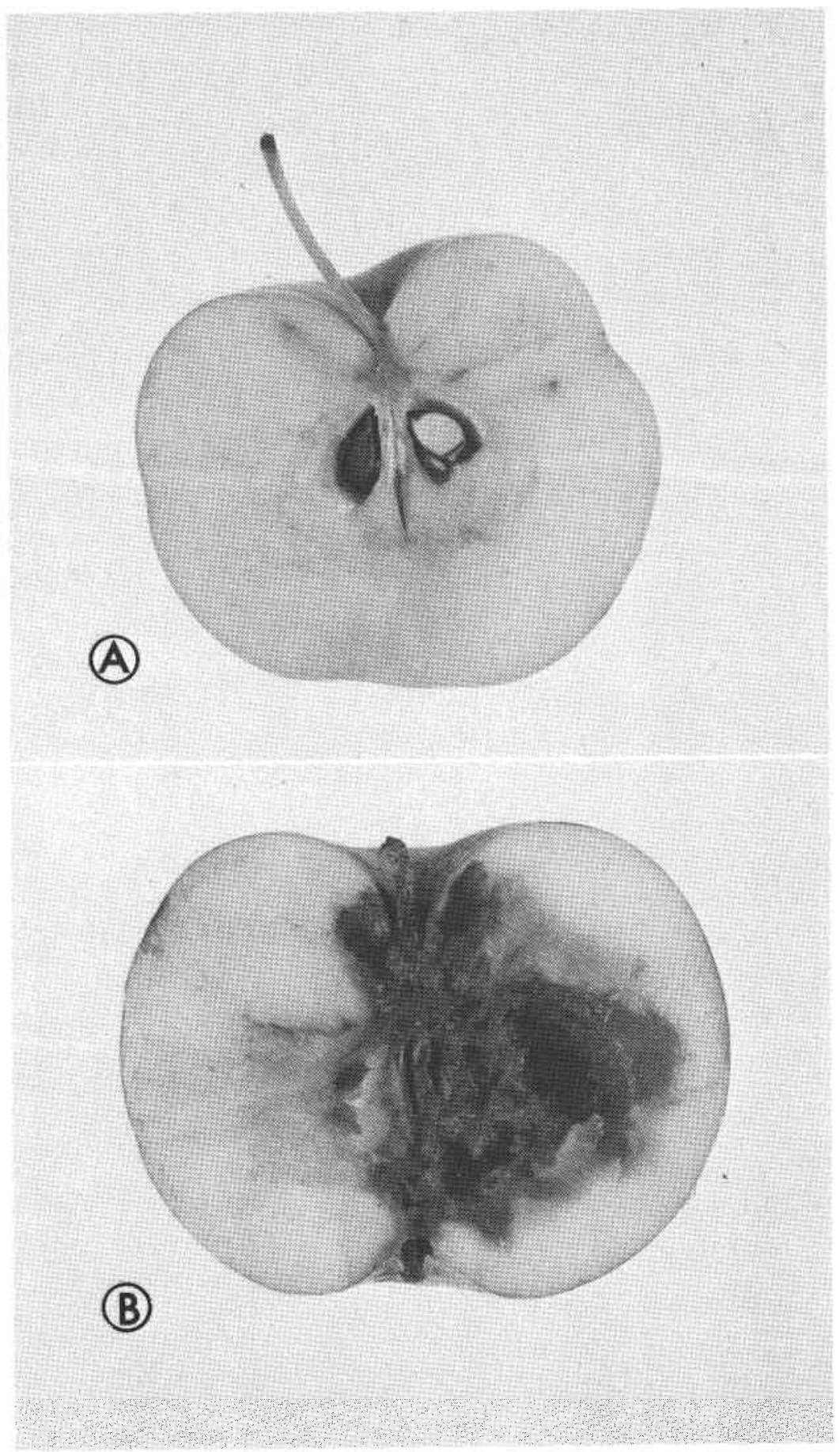

Fig. 1. A, Rome apple infested on the tree 2 July-9 July, in which apple maggot larvae died early. B, McIntosh apple infested on the tree from 29 August to 6 September, in which apple maggot larvae completed development. 
developed more rapidly in apples infested in late June and July than in those infested in August and September. These differences may have been due both to the gradually declining temperatures and chemical or physical changes occurring in the maturing fruit.

Similar differences in the survival of larvae of the Queensland fruit fly in picked and unpicked apples have been observed by Bower (1977). The cause of the heavy mortality of apple maggot larvae in unpicked apples has not been identified, but this study suggests that variations in larval survival previously reported among cultivars are due to interactions between the larvae and the immature host fruit while it is on the tree rather than after it has matured and dropped or been harvested. Flesh texture and firmness have been reported to affect the survival of larvae in various apple cultivars (Dean and Chapman 1973; Neilson 1976), and the same factors may be responsible for larval mortality in unpicked fruit. However, chemical differrences between harvested apples and those remaining on the tree may also have caused some of the differences in larval mortality observed here.

Most apple maggot larvae would die in fruit infested in June and July in New York because almost all commercially grown apples are later-maturing cultivars. The slight damage caused by the small larvae before they die is unacceptable commercially, and early-season control sprays are necessary to prevent damage in orchards that contain apple maggot infestations or are near sources of reinfestation. However, if a system were developed in the future to monitor small numbers of indigenous or immigrating apple maggot flies, early season sprays can be reduced in blocks of later maturing cultivars containing the flies. Damage would be slight because only a few apples would be infested and larval mortality would be high.

\section{Acknowledgments}

I thank H.E. Hebding, D.C. Smith, H.C. Cooley, and N.E. Christensen for providing technical assistance, and G.A. Catlin and R.M. McMillen for preparing the illustrations in this manuscript.

\section{References}

Bower, C. C. 1977. Inhibition of larval growth of Queensland Fruit Fly, Dacus tryoni (Diptera: Tephritidae) in apples. Ann. ent. Soc. Am. 70:97-100.

Brittain, W. H. and C. A. Good. 1917. The apple maggot in Nova Scotia. Bull. N.S. Dep. Agric. 9. 70 pp

Caesar, L. and W. A. Ross. 1919. The apple maggot. Bull. Ont. Dep. Agric. 271. 32 pp.

Cameron, P. J. and F. O. Morrison. 1977. Analysis of mortality in the apple maggot, Rhagoletis pomonella (Diptera: Tephritidae), in Quebec. Can. Ent. 109: 769-788.

Dean, R. W. and P. J. Chapman. 1973. Bionomics of the apple maggot in eastern New York. Search Agric. 3(10): 64 pp.

Neilson, W. T. A. 1976. The apple maggot (Diptera: Tephritidae) in Nova Scotia. Can. Ent. 108: 885-892.

Neilson, W. T. A. and J. W. McAllan. 1965. Artificial diets for the apple maggot. III. Improved, defined diets. J. econ. Ent. 58: 542-543.

(Received 19 April 1978) 